\title{
Biological and ecological studies on Scymnus syriacus and Scymnus levaillanti (Coleoptera: Coccinellidae)
}

\author{
ThaBet F. ALLAWI \\ University of Jordan, Faculty of Agriculture, Plant Protection Department, Amman, Jordan; e-mail: thabet@ju.edu.jo
}

Key words. Scymnus syriacus, Scymnus levaillanti, aphidophagous coccinellids, oviposition, developmental time, longevity, food consumption

\begin{abstract}
Both Scymnus syriacus Mars. and Scymnus levaillanti Muls. are aphidophagous coccinellids. In the laboratory they consumed and successfully reproduced on several species of aphids. Larvae suck the prey contents from aphid appendages, while adults consume the whole aphid, except for parts of the appendages. Extra-oral digestion is practiced during feeding. The mean number of aphids consumed by the larval stage of $S$. syriacus when reared at $25^{\circ} \mathrm{C}$ was 95 , and 130 aphids at $30^{\circ} \mathrm{C}$. For $S$. levaillanti it was 125 and 139 aphids at $25^{\circ} \mathrm{C}$ and $30^{\circ} \mathrm{C}$, respectively. The mean number of eggs deposited daily by $S$. syriacus for the first three weeks of adult life was 19.5 , with a range of $3-30$ eggs at $25^{\circ} \mathrm{C}$. Longevity of adults ranged from 3 to 4 months at $25^{\circ} \mathrm{C}$ and $2.5-3$ months at $30^{\circ} \mathrm{C}$.
\end{abstract}

\section{INTRODUCTION}

This study is one of several on coccinellids in Jordan. Scymnus syriacus Mars. and Scymnus levaillanti Muls. both are aphidophagous species. There are 44 coccinellid species found in Jordan; many are associated with insect and mite pests: aphids, whiteflies, scale insects and spider mites. A list of sixteen predaceous coccinellids was published (Allawi, 1989), of which aphidophagous coccinellids were the most common. Collected coccinellids were identified by C.A.B. International Institute of Entomology, London, UK.

Aphidophagous coccinellids are found throughout the world in association with aphids and other insects, especially homopteran pests. More than 5000 species of Coccinellidae have been described (Frazer, 1988).

Coccinellids have been studied intensively but their impact on aphid populations in crops has only been reported in some cases (Hodek \& Honěk, 1996; Obrycki \& Kring, 1998). In contrast to successful cases of introductions of coccidophagous ladybirds, aphidophagous coccinellids are not promising candidates for classical biological control because of the unfavourable predator/prey ratio of the annual number of generations (Hodek, 1973, p. 215; Hagen, 1974; Hodek \& Honěk, 1996, p. 352; Dixon, 1997; Kindlmann \& Dixon, 1999).

Many biological control experiments were performed with aphidophagous ladybirds on sugar cane, cotton, apple trees and in greenhouses (Ferran et al., 1996). Their efficacy in natural or managed systems is difficult to determine given their mobility and typically polyphagous nature (Obrycki \& Kring, 1998). When adults of Hippodamia convergens Guerin were released in North America to control Aphis gossypii Glover on cantalopes the adults disappeared and the attempt failed (Hagen, 1962).

Coccinellid developmental rates depend on the ambient temperature (Saona \& Miller, 1999). Studies on temperature dependent development, important for understanding the dynamics of predator-prey relationship, have been undertaken relatively well for aphidophagous coccinellids in temperate zones (Lamana \& Miller, 1998). Moreover, temperature determines the conditions for efficient mass rearing, provide a quantitative basis for predicting development and predatory activity in pest management programmes, and are used in models to esti- mate insect growth, development and reproduction (Saona \& Miller, 1999).

The objective of this study of $S$. levaillanti and S. syriacus is to list their aphid prey and host plants, and to determine the effect of temperature on developmental rate and prey consumption, when the coccinellids were fed on the melon aphid Aphis gossypii Glover.

\section{MATERIAL AND METHODS}

Adults of Scymnus syriacus Mars. and Scymnus levaillanti Muls. were collected during May from the Jordan Valley, Irbid and other areas of Jordan during the spring and summer seasons. Their F1 progeny were used to assess developmental rates, prey consumption and egg deposition for about three weeks. Adults were reared in the laboratory at $25 \pm 1{ }^{\circ} \mathrm{C}$ and $30 \pm 1{ }^{\circ} \mathrm{C}$ and fed on melon aphids $A$. gossypii Glover, which had been cultured in a greenhouse on okra plants Aloemescus esculentus L.

To record precisely the different biological parameters, the insects were observed at six hour intervals, also at night.

The collected females were confined for 4-6 $\mathrm{h}$ for oviposition. Eggs were collected with a fine brush and placed in Petri dishes on okra leaves. Newly hatched larvae were placed individually in $5 \mathrm{~cm}$ Petri dishes furnished with a moistened filter paper at the bottom, and a piece of okra leaf $3-4 \mathrm{~cm}$ in diam. with 20-25 aphids. The larvae were moved daily to new Petri dishes. To assure a surplus of prey, the number of aphids in Petri dishes was increased to 40 for the $3^{\text {rd }}$ and $4^{\text {th }}$ instars. Petri dishes were incubated at $25 \pm 1{ }^{\circ} \mathrm{C}$ and $30 \pm 1^{\circ} \mathrm{C}$ and a photoperiod of 16L: 8D. Incubation period was recorded by observing egg hatching and developmental time for each larval instar and pupa by ecdysis. Aphid consumption was recorded at the two tested temperatures. Egg deposition was recorded at $25^{\circ} \mathrm{C}$ for three weeks.

Statistical analysis was conducted to test for the effects of temperature on developmental rates, and consumption was tested by analysis of variance using complete randomized design, means with significant differences were detected and compared using L.S.D. tests, which significance taken at $\mathrm{P}=$ 0.05 . 
TABLE 1. Duration (in hours) of developmental stages of Scymnus syriacus at $25^{\circ} \mathrm{C}$ and $30^{\circ} \mathrm{C}$.

\begin{tabular}{lcccccccc}
\hline Temp. $\left({ }^{\circ} \mathrm{C}\right)$ & $\mathrm{n}$ & Egg & 1st instar & 2nd instar & 3rd instar & 4th instar & Prepupa & Pupa \\
\hline $25 \pm 1$ & 15 & $110.0 \pm 0.51 \mathrm{a}$ & $42.0 \pm 1.5 \mathrm{a}$ & $25.50 \pm 0.75 \mathrm{a}$ & $25.60 \pm 0.75 \mathrm{a}$ & $46.20 \pm 1.93 \mathrm{a}$ & $23.0 \pm 0.38 \mathrm{a}$ & $144 \pm 3.1 \mathrm{a}$ \\
$30 \pm 1$ & 15 & $70.67 \pm 0.39 \mathrm{~b}$ & $36.60 \pm 0.95 \mathrm{~b}$ & $19.50 \pm 0.19 \mathrm{~b}$ & $21.47 \pm 0.64 \mathrm{~b}$ & $33.90 \pm 0.90 \mathrm{~b}$ & $17.70 \pm 0.18 \mathrm{~b}$ & $107 \pm 2.6 \mathrm{~b}$ \\
L.S.D. & & 3.037 & 1.035 & 0.818 & 0.739 & 1.51 & 0.739 & 2.903 \\
\hline
\end{tabular}

\section{RESULTS}

\section{Biology of $S$. syriacus}

Both larvae and adults were observed foraging and capturing their prey. Adults can survive when fed on the lentil aphid Aphis craccivora Koch, rose aphid Macrosiphum rosae (L.), pomegranate aphid Aphis punicae Passerini and oleander aphid Aphis nerii Boyer de Fons. Their main prey in the field was the melon aphid A. gossypii, feeding on different host plants including citrus, okra, white flower gourd, guava and convolvulus.

Mating takes place within two days of adult emergence and the deposition of fertile eggs begins five days later. Mating is necessary for the production of fertile eggs. The reproduction period continued for several months, and hundreds of eggs were produced. Females deposit their eggs individually, they are laid horizontally on the leaf surface, and covered either by aphid exuvia or parts of the plant leaf. Eggs are spindle shaped and golden to light brown in color, and just prior to hatching, the egg chorion becomes transparent showing the darkened embryo inside.

The first instar larva is shiny pale yellow to orange. They lack the waxy material formed as slender short thread secretions that appear on the subsequent instars $1-2 \mathrm{~h}$ after moulting. The young coccinellid larvae usually pierce and suck the content from the prey. The number of aphids killed depends on the size of the aphid species, developmental stage of the coccinellid and the ambient temperature. The very mobile 3rd and 4th instars actively search for colonies of aphids.

Pre-oral digestion is practiced during feeding; prey fluid contents are sucked out and repeatedly pumped back into the body of the prey, thus effecting a rapid and thorough mixing with the digestive juices. In case of food shortage the larvae become cannibalistic.

Moulting takes from 20-30 min. Before moulting the larva fixes its abdominal end to the substrate by black, heavy, liquid secretions from the anus, its body becoming shorter. The shiny and transparent cuticle splits dorsally starting from the dorsal anterior part of the body. The larva emerges from the exuvium through this split. Pupation occurs in nature in sheltered places, one day after the beginning of the prepupal stage, when a dorsal median split of the anterior part of the body is formed. The duration of the immature stages depends on temperature and prey species. Prey shortage prolongs larval development and increases mortality.

\section{Developmental time of Scymnus syriacus}

The total developmental time for $S$. syriacus was on average 17.3 days at $25^{\circ} \mathrm{C}$ and 12.8 days at $30^{\circ} \mathrm{C}$, but its duration varied significantly. The time to egg hatch, duration of the larval instars and pupal stage are represented in Table 1. All stages required significantly longer developmental period at $25^{\circ} \mathrm{C}$ than at $30^{\circ} \mathrm{C}$. At $25^{\circ} \mathrm{C}$ the fourth larval instar required a longer developmental period than others, followed by the first instar without a significant difference between the first and the fourth instar, while at $30^{\circ} \mathrm{C}$ the first instar was the longest, followed by the fourth. The greater duration of the $1^{\text {st }}$ instar might be caused by low rates of prey capture, as the larva moves slowly and its ability to successfully attack prey is low.

\section{Developmental time of Scymnus levaillanti}

The total developmental time ranged from 10.7 days at $30^{\circ} \mathrm{C}$ to 14.7 days at $25^{\circ} \mathrm{C}$ with a significant difference between the tested temperatures. The duration of the egg incubation period, larval and pupal stages at $25^{\circ} \mathrm{C}$ and $30^{\circ} \mathrm{C}$ are presented in Table 2. All stages required significantly longer periods at $25^{\circ} \mathrm{C}$ than at $30^{\circ} \mathrm{C}$. At both tested temperatures developmental time of the $4^{\text {th }}$ larval instar was longer than the first instar. The developmental time of the pupal stage was longer than that of the $4^{\text {th }}$ instar, which agrees with Uygun \& Atlihan (2000). However, the time needed to develop from egg to adult was not the same in their experiment.

\section{Prey consumption}

The mean number of aphids consumed during the larval stage of $S$. syriacus at $25^{\circ} \mathrm{C}$ was 95.5 aphids and 130.1 aphids at $30^{\circ} \mathrm{C}$, with a significant difference between the two tested temperatures. While for $S$. levaillanti, the average number consumed at $25^{\circ} \mathrm{C}$ was 125 aphids and at $30^{\circ} \mathrm{C}$ it was 138.8 aphids. The $4^{\text {th }}$ instar larvae are the most voracious. The daily consumption of food by larvae is proportional to their size. The average number of aphids consumed by individual larval instars is presented in Table 3.

\section{Oviposition and longevity}

The reproductive capacity of these species is often relatively high, and the extension of the oviposition period is closely related to temperature and prey availability. The total egg deposition and rate of oviposition are affected both by temperature and the availability of suitable food. This agrees with the results obtained by Uygun \& Atlihan ( 2000 ).

Adults began egg deposition five days after emergence. The longevity of adults ranged from 3 to 4 months ( $82-110$ days) at $25^{\circ} \mathrm{C}$ to $2.5-3$ months (70-97 days) at $30^{\circ} \mathrm{C}$.

\section{DISCUSSION}

Uygun \& Atlihan (2000) and Isikber \& Copland (2001) found that $S$. levaillanti is associated with $A$. gossypii on citrus and cotton plants in Turkey. In Jordan, both coccinellid species under consideration here were found during spring and summer in association with several aphid species (see Results), attacking different plants in addition to okra in the uplands, a rain fed area.

TABLE 2. Duration (in hours) of developmental stages of Scymnus levaillanti at $25^{\circ} \mathrm{C}$ and $30^{\circ} \mathrm{C}$.

\begin{tabular}{lcccccccc}
\hline Temp. $\left({ }^{\circ} \mathrm{C}\right)$ & $\mathrm{n}$ & Egg & 1st instar & 2nd instar & 3rd instar & 4th instar & Prepupa & Pupa \\
\hline $25 \pm 1$ & 20 & $99 \pm 0.42 \mathrm{a}$ & $43.85 \pm 0.33 \mathrm{a}$ & $26.7 \pm 0.31 \mathrm{a}$ & $28.2 \pm 0.32 \mathrm{a}$ & $38.85 \pm 0.41 \mathrm{a}$ & $22 . \pm 0.21 \mathrm{a}$ & $93.2 \pm 0.54 \mathrm{a}$ \\
$30 \pm 1$ & 20 & $78.3 \pm 0.46 \mathrm{~b}$ & $23.1 \pm 0.16 \mathrm{~b}$ & $19.15 \pm 0.10 \mathrm{~b}$ & $20 . \pm 0.22 \mathrm{~b}$ & $27.6 \pm 0.34 \mathrm{~b}$ & $15.9 \pm 0.16 \mathrm{~b}$ & $73.5 \pm 0.42 \mathrm{~b}$ \\
L.S.D. & & 1.462 & 0.907 & 0.886 & 0.698 & 1.104 & 0.73 & 1.26 \\
\hline
\end{tabular}


TABLE 3. The average number of aphids (Aphis gossypii) consumed by larval instars of Scymnus syriacus and Scymnus levaillanti.

\begin{tabular}{lcccccc}
\hline \multirow{2}{*}{ Coccinellid sp. } & Temp. & $\mathrm{n}$ & \multicolumn{4}{c}{ Aphid consumption } \\
\cline { 5 - 7 } & & & 1st instar & 2nd instar & 3rd instar & 4th instar \\
\hline S. syriacus & $25 \pm 1$ & 15 & $3.93 \pm 0.30 \mathrm{a}$ & $9.13 \pm 0.80 \mathrm{a}$ & $24.93 \pm 0.80 \mathrm{a}$ & $57.47 \pm 2.30 \mathrm{a}$ \\
& $30 \pm 1$ & 15 & $5.6 \pm 0.25 \mathrm{~b}$ & $16.53 \pm 0.38 \mathrm{~b}$ & $27.87 \pm 0.83 \mathrm{~b}$ & $80.61 \pm 2.80 \mathrm{~b}$ \\
& L.S.D. & & 0.539 & 1.244 & 1.85 & 4.45 \\
S. levaillanti & $25 \pm 1$ & 15 & $5.15 \pm 0.40 \mathrm{a}$ & $14.70 \pm 0.30 \mathrm{a}$ & $39.15 \pm 1.5 \mathrm{a}$ & $66.05 \pm 3.2 \mathrm{a}$ \\
& $30 \pm 1$ & 15 & $8.40 \pm 0.30 \mathrm{~b}$ & $19.40 \pm 0.90 \mathrm{~b}$ & $47.70 \pm 1.3 \mathrm{~b}$ & $63.30 \pm 2.8 \mathrm{~b}$ \\
& L.S.D. & & 0.699 & 1.79 & 2.63 & 4.86 \\
\hline
\end{tabular}

Slight differences in the duration of instars and total developmental time of $S$. levaillanti were found in this experiment, compared with other studies (Uygun \& Atlihan, 2000; Isikber \& Copland, 2001). This was probably a result of their less frequent observations and overlapping larval instars. Also the specific characteristics of aphid species, used as prey, might result in differences in developmental time, immature mortality and adult weight of the predators. Coccinellids have the ability to also survive on alternative prey when the main aphid prey are in short supply (Hoffman \& Frodsham, 1993; Hodek \& Honěk, 1996). Location of habitat, plant host and aphid prey may affect predation efficiency (Hodek, 1993). While Dixon (1959) assumed that the searching behavior of Adalia decempunctata is generally random, Nakamuta (1984) reported that in the light adults of Coccinella septempunctata oriented themselves towards aphid prey, while they failed in the dark. However it is noted here that the number of prey killed when lights were off was not significantly different than when the lights were on, assuming that prey were abundant. So, there may be cues, other than optical, that attract coccinellids to their prey (Pettersson et al., 2005)

In spite of promising results, aphidophagous coccinellids have rarely been used in plant protection (e.g. Ferran et al., 1996) This is mainly due to the complexity and cost of their mass production, which requires a simultaneous rearing of predators and aphids on a given plant, usually in artificial conditions. A simplification of rearing techniques is necessary to make ladybird production cheaper and to promote their use in biological control, specially for inundative release. The simplification would involve using suitable substitute prey or artificial diets (Hodek \& Honěk, 1996), but in such rearings slower larval development, higher larval mortality and low or no reproduction were sometimes reported. However, the two aphidophagous species under study here were easy to handle in the laboratory and proved to be voracious predators; thus they might be considered promising candidates for augmentative biocontrol.

ACKNOWLEDGEMENTS. The author is indebted to the Deanship of Scientific Research at The University of Jordan for financial supporting this work. Thanks are also due to I. Hodek, Institute of Entomology, Academy of Science of the Czech Republic, for his valuable suggestions.

\section{REFERENCES}

Allawi T.F. 1989: A list of predaceous coccinellids collected in Jordan. Derasat 16: 23-26.

Dixon A.F.G. 1959: An experimental study of the searching behavior of the predatory coccinellid beetle Adalia decempunctata (L.). J. Anim. Ecol. 28: 259-281.

Dixon A.F.G. 1997: Effectiveness of ladybirds as biological control agent: Patterns and processes. Entomophaga 42: $71-83$.
Ferran A. \& Dixon A.F.G. 1993: Foraging behavior of ladybird larvae (Coleoptera: Coccinellidae). Eur. J. Entomol 90: 383-402.

Ferran A., Niknam H., Kabiri F., Picart J., Herce C., Burn J., IPERTI G. \& LAPCHIN L. 1996: The use of Harmonia axyridis larvae (Coleoptera: Coccinellidae) against Macrosiphum rosae (Hemiptera: Aphididae) on rose bushes. Eur. J. Entomol. 93: 59-67.

Frazer B.D. 1988: Coccinellidae. In Minks A.K. \& Harrewijn P.: Aphids, their Biology, Natural Enemies and Control. Vol. 2B. Elsevier, Amsterdam, pp. 231-247.

HAGEN K.S 1962: Biology and ecology of predacious Coccinellidae. Annu. Rev. Entomol. 7: 289-326.

HAGEN K.S. 1974: The significance of predaceous Coccinellidae in biological and integrated control of insects. Entomophaga (Mem. Hors Serie) 7: 25-44.

Hodek I. 1973: Biology of Coccinellidae. Academia, Prague \& Junk, The Hague, $260 \mathrm{pp}$.

Hodek I. 1993: Habitat and food specificity in aphidophagous predators. Biocontr. Sci. Technol. 3: 91-100.

Hodek I. \& HonĚK A. 1996: Ecology of Coccinellidae. Kluwer, Dordrecht, $464 \mathrm{pp}$.

Hoffman M. \& Frodsham A. 1993: Natural Enemies of Vegetable Insect Pests. Cooperative extension, Cornell University, Ithaca, $63 \mathrm{pp}$

IsIKBER A.A. \& Copland M.J.W. 2001: Food consumption and utilisation by larvae of two coccinellid predators, Scymnus levaillanti and Cycloneda sanguinea, on cotton aphid, Aphis gossypii. Biocontrol 46: 455-467.

KindlMAnN P. \& Dixon A.F.G. 1999: Generation time ratios determinants of prey abundance in insect predator-prey interactions. Biol. Contr. 16: 133-138.

Lamana M. \& Miller J. 1998: Temperature dependent development in an Oregon population of Harmonia axyridis (Coleoptera: Coccinellidae). Environ. Entomol. 27: 1001-1005.

NAKAMUTA K. 1984: Visual orientation of a ladybeetle Coccinella septempunctata (Col. Coccinellidae), towards its prey. Appl. Entomol. Zool. 19: 82-86.

OBRYCKI J. \& KRING T. 1998: Predacious Coccinellidae in biological control. Annu. Rev. Entomol. 43: 295-321.

Pettersson J., Ninkovic V., Glinwood R., Birkett M.A. \& PicKeTt J.A. 2005: Foraging in a complex environment semiochemicals support searching behaviour of the seven spot ladybird. Eur. J. Entomol. 102: 365-370.

SaOna C. \& Miller J. 1999: Temperature dependent effects on development, mortality and growth of Hippodamia convergens (Coleoptera: Coccinellidae). Environ. Entomol. 28: 518-522.

Uygun N. \& Atlihan R. 2000: The effect of temperature on development and fecundity of Scymnus levaillanti. Biocontrol 45: 453-462.

Received September 10, 2004; revised and accepted October 24, 2005 